\title{
The Effect of Lactose on the Intestinal Absorption of Calcium and Zinc in the Rat during Maturation
}

\author{
FAYEZ K. GHISHAN, ${ }^{(23)}$ STEVE STROOP, AND RAYMOND MENEELY \\ Vanderbilt Medical Center, Division of Gastroenterology/Nutrition, Nashville, Tennessee, USA
}

\section{Summary}

Lactose facilitates the intestinal absorption of several minerals and trace elements in postweanling rats. There is no information in the literature on the effect of lactose on the process of absorption in suckling rats.

Because soy and elemental formulas are nonlactose-containing diets, the role of lactose in facilitating the intestinal absorption of minerals is of considerable nutritional importance.

We studied therefore, the effect of water (control), lactose, sucrose, and glucose on the intestinal absorption and tissue uptake of calcium and zinc in the suckling (14-15 day old) and adolescent (42-43 day old) rats.

Our results indicate that absorption of calcium and zinc was significantly greater in the suckling than in adolescent rats $(P<$ 0.01). Lactose enhanced significantly the absorption and tissue uptake of calcium and zinc in the adolescent rats compared to control and other sugars.

In the suckling rats lactose had no effect on the intestinal absorption or tissue uptake of calcium and zinc compared to control and other sugars. The possible mechanism(s) responsible for our findings are discussed.

\section{Speculation}

Lactose enhances the intestinal absorption of minerals in the adolescent but not in the suckling rat. This finding may be related to differences in the permeability of the intestinal membranes, which occurs during maturation.

The role of essential minerals and trace elements in infant nutrition is now well established. Lactose facilitates the intestinal transport of several minerals such as calcium (3), iron (2), zinc (7), manganese (8), cobalt (9), magnesium, strontium, barium, and radium (14). Human and cow's milk contains lactose as the only source of carbohydrates. On the other hand, soy formulas, in which sucrose is the main source of carbohydrates, are currently fed with increasing frequency to infants. Furthermore, the elemental formulas are nonlactose-containing diets; thus, the role of lactose in facilitating the intestinal absorption of calcium and other minerals and trace elements is of considerable nutritional importance.

All the available studies in the literature on the effect of lactose on mineral absorption were carried out in postweanling animals $(2,3,7,8,9,14)$. At this age the animal's diet contains exclusively sucrose, and/or cornstarch as the source of carbohydrate, in contrast with the suckling rats diet, which contains lactose as the source of carbohydrate; moreover, lactase activity in the brush border membrane of the rat intestine declines markedly after weanling, in contrast with high activity in the suckling rat intestine $(11,13)$

The available information on the effect of lactose on mineral absorption may not reflect the events that occur in the suckling animal. We studied, therefore, the effect of water, glucose, sucrose, and lactose on the intestinal absorption of calcium, an essential mineral, and zinc, an essential trace element. The groups of rats studied were the suckling (14-15 day old) and adolescent (42-43 day old).

\section{MATERIALS AND METHODS}

On the second day after birth, rat pups (Harland Industries, Indianapolis, IN) were randomized among the mothers and litter size was maintained at eight to nine until the time of the study. Adolescent rats were purchased directly from Harland Industries.

Dams and adolescent rats were fed a regular laboratory diet (Rat Diet, Teklad Diets, Madison, WI). This diet contains 1.2\% calcium, $0.8 \%$ phosphorus, $0.005 \%$ zinc and $170 \mathrm{U} / 100 \mathrm{~g}$ of vitamin $D_{2}$. Suckling rats were studied at $14-15$ days and adolescent rats at $42-43$ day after birth.

Calcium absorption studies. On the day of the study, under light ether anesthesia, a $0.5 \mathrm{ml}$ dosing solution containing $0.5 \mu \mathrm{Ci}$ of ${ }^{45} \mathrm{Ca}, 50 \mu \mathrm{g} \mathrm{CaCl}_{2}$ as a carrier, and a test dose of $3 \mathrm{mg}$ of lactose, sucrose or glucose per $\mathrm{g}$ of body weight was administered by gavage. The administered dose of sugars lies in the physiologic range found in the small intestine of the rat (5).

After dosing, the animals fasted overnight and were killed the next day by ether overdose. Blood was obtained from the aorta, the liver, kidneys, femur, the entire gastrointestinal tract from the esophagus to the rectum, and all feces were collected, weighed and placed in $20 \mathrm{ml}$ plastic scintillation vials. Tissues were dissolved in $1 \mathrm{ml}$ of concentrated nitric acid then ashed. Ten $\mathrm{ml}$ of scintillation fluid was then added to the ashed tissues. Radioactivity was assayed in Beckman LS 300 liquid scintillation spectrophotometer.

To assess calcium uptake by specific organs, counts were converted to counts per min (CPM) per $\mathrm{g}$ of tissues and compared to standard composed of the initial dosing solution diluted to about $1 \mathrm{ml}$ of distilled water. The \% absorption from the gut was calculated by difference according to Smith et al. (19) as follows:

$$
\% \text { absorption }=\frac{100 \mathrm{CPM} \text { std. }-\mathrm{CPM} \text { gut }+ \text { feces }}{\text { CPM std. }}
$$

Statistical analysis. Unpaired comparisons between two means was tested for significance using student's $t$-test. Multiple mean comparisons of unpaired data to the control group was made using one-way analysis of variance then Dunnett's procedure. The level of significance was chosen as $(P<0.05)(4)$.

Zinc absorption studies. These studies were conducted in a similar fashion to calcium studies. The dosing solution of $0.5 \mathrm{ml}$ contained $0.5 \mu \mathrm{Ci}{ }^{65} \mathrm{Zn}, 5 \mu \mathrm{g}$ zinc $\mathrm{Cl}_{2}$ as carrier, and a test dose of $3 \mathrm{mg}$ of lactose, sucrose, or glucose per $\mathrm{g}$ of body weight. Tissues and blood samples of the rats studied were counted in a gamma counter (Packard Model 3001). Calculations were carried out as described for calcium studies.

\section{RESULTS}

Table 1 depicts the effect of water, glucose, sucrose, and lactose treatment on absorption and tissue uptake of calcium. In the suckling rat, absorption of calcium from the gut was similar in all 
treatment groups 98-99\%. Uptake of calcium in the femur was approximately $20 \%$ of the ingested dose, which was significantly greater than corresponding mean uptake in the kidneys and liver tissue. Uptake to various organs, was similar in all treatment groups.

In the adolescent rats, absorption of calcium and uptake by femur, kidney, liver and blood tissues was significantly enhanced with lactose treatment compared to mean absorption values with water (control), glucose and sucrose treatment groups. Similar to the observation in the suckling rat, calcium uptake into the femur was significantly greater than uptake by kidney and liver tissues.

When calcium absorption and uptake by various tissue in the suckling and adolescent rats were compared, there were marked differences. Absorption and tissue uptake of calcium were significantly greater in each treatment of the suckling rats compared to corresponding mean values in the adolescent group $(P<0.01)$.

Table 2 depicts the effect of water, glucose, sucrose, and lactose treatment on absorption and tissue uptake of ${ }^{65} \mathrm{Zn}$. Similar to calcium studies in the suckling rats, there were no significant differences in the absorption or tissue uptake of zinc between the various treatments studied. Uptake of zinc into the liver was significantly greater than corresponding mean uptake to the femur and kidneys.

In the adolescent rats, absorption of zinc was significantly enhanced by lactose compared to water, glucose and sucrose. Zinc uptake by femur, kidney, liver, and blood was significantly enhanced by lactose when compared to water (control) and glucose but not to sucrose.

When absorption and tissue uptake of zinc was compared between suckling and adolescent rats in the various treatment groups, there was significantly greater absorption and tissue uptake of zinc in the suckling rats compared to the adolescent rats in all treatment groups $(P<0.001)$.

\section{DISCUSSION}

The data show that lactose enhances absorption and tissue uptake of calcium and zinc in the adolescent but not in the suckling rat. The data on the adolescent rats agree with previously published data on the effect of lactose on mineral absorption in the actively growing postweanling rats $(2,3,7,8,9,14)$. The current study is the first to demonstrate the effect of various sugars on the absorption of minerals and trace elements in suckling animals. The data indicate that mean absorption of calcium and zinc in the suckling rats was significantly greater than corresponding mean values in the adolescent rats. Tissue uptake of calcium and zinc expressed as CPM/g wet weight in the femur, kidney, liver and blood was significantly greater in the suckling than in the adolescent rats. These findings are in agreement with our in vivo perfusion studies on calcium (10), magnesium (17), and zinc (16) in the rat during maturation. Also, these results are in agreement with previously published in vitro studies $(1,12,18)$. It is interesting to note that in the suckling rat, lactose did not enhance either calcium or zinc absorption and tissue uptake compared to water (control) glucose or sucrose.

The mechanisms by which lactose facilitated calcium and other mineral absorption is not well understood. The recent observation that lactose also enhances the absorption of a nonessential toxic metal as lead suggests the nonspecificity of the action of lactose (5). It has been proposed that lactose might increase calcium absorption by forming an uncharged complex with calcium (6),

Table 1. The effect of water, glucose, sucrose, and lactose on absorption and tissue uptake of ${ }^{45}$ calcium in the rats studied ${ }^{2}$

\begin{tabular}{|c|c|c|c|c|c|c|}
\hline \multirow[b]{2}{*}{ Treatment } & \multirow[b]{2}{*}{ Dose $(\mathrm{mg} / \mathrm{g})$} & \multirow[b]{2}{*}{ Absorption (\%) } & \multicolumn{4}{|c|}{ Uptake by } \\
\hline & & & Femur $(\%)$ & Kidney (\%) & Liver $(\%)$ & Blood (\%) \\
\hline \multicolumn{7}{|l|}{ Suckling rat } \\
\hline Water (control) & 0 & $99 \pm 0.1^{2}$ & $18 \pm 2.3^{2}$ & $0.18 \pm 0.3$ & $0.11 \pm 0.03^{2}$ & $0.2 \pm 0.4^{2}$ \\
\hline Glucose & 3 & $99 \pm 0.1^{2}$ & $23 \pm 3.0^{2}$ & $0.22 \pm 0.03^{2}$ & $0.16 \pm 0.04^{2}$ & $0.3 \pm 0.1^{2}$ \\
\hline Sucrose & 3 & $98 \pm 0.4^{2}$ & $23 \pm 3.7^{2}$ & $0.19 \pm 0.04^{2}$ & $0.14 \pm 0.04^{2}$ & $0.3 \pm 0.06^{2}$ \\
\hline Lactose & 3 & $99 \pm 0.1^{2}$ & $23 \pm 3.0^{2}$ & $0.24 \pm 0.05^{2}$ & $0.11 \pm 0.03^{2}$ & $0.2 \pm 0.03^{2}$ \\
\hline \multicolumn{7}{|l|}{ Adolescent rat } \\
\hline Water (control) & 0 & $89 \pm 1.9$ & $4.3 \pm 0.4$ & $0.03 \pm 0.003$ & $0.02 \pm 0.003$ & $0.02 \pm 0.003$ \\
\hline Glucose & 3 & $88 \pm 3.7$ & $3.6 \pm 0.2$ & $0.02 \pm 0.002$ & $0.01 \pm 0.002$ & $0.01 \pm 0.001$ \\
\hline Sucrose & 3 & $89 \pm 2.7$ & $3.7 \pm 0.4$ & $0.02 \pm 0.002$ & $0.01 \pm 0.002$ & $0.01 \pm 0.002$ \\
\hline Lactose & 3 & $97 \pm 0.7^{3}$ & $6.8 \pm 0.9^{3}$ & $0.06+0.01^{3}$ & $0.03 \pm 0.01^{3}$ & $0.05 \pm 0.01^{3}$ \\
\hline
\end{tabular}

${ }^{1}$ Values are mean \pm S.E., $8-10$ rats were used in each treatment group.

${ }^{2}$ Mean values in the suckling rats were significantly greater than corresponding mean values in the adolescent rats $(P<0.05-0.001)$

${ }^{3}$ Mean values in the lactose fed adolescent rats are significantly greater than corresponding mean values in rats fed water, glucose, and sucrose $(P$ $<0.05)$.

Table 2. The effect of water, glucose, sucrose, and lactose on absorption and tissue uptake of ${ }^{65}$ Zinc $^{1}$

\begin{tabular}{|c|c|c|c|c|c|c|}
\hline \multirow[b]{2}{*}{ Treatment } & \multirow[b]{2}{*}{ Dose $(\mathrm{mg} / \mathrm{g})$} & \multirow[b]{2}{*}{ Absorption (\%) } & \multicolumn{4}{|c|}{ Uptake By } \\
\hline & & & Femur (\%) & Kidney $(\%)$ & Liver $(\%)$ & Blood (\%) \\
\hline \multicolumn{7}{|l|}{ Suckling rat } \\
\hline Water (control) & 0 & $90 \pm 1.6^{2}$ & $8 \pm 0.4^{2}$ & $6 \pm 0.7^{2}$ & $22 \pm 1.0^{2}$ & $1.3 \pm 0.1^{2}$ \\
\hline Glucose & 3 & $91 \pm 1.8^{2}$ & $5 \pm 0.2^{2}$ & $6 \pm 0.4^{2}$ & $21 \pm 2.0^{2}$ & $1.9 \pm 0.3^{2}$ \\
\hline Sucrose & 3 & $89 \pm 1.9^{2}$ & $6 \pm 0.4^{2}$ & $8 \pm 0.2^{2}$ & $32 \pm 3.0^{2}$ & $1.3 \pm 0.2^{2}$ \\
\hline Lactose & 3 & $86 \pm 1.2^{2}$ & $6 \pm 0.5^{2}$ & $6+1.1^{2}$ & $24 \pm 1.0^{2}$ & $1.3 \pm 0.1^{2}$ \\
\hline \multicolumn{7}{|l|}{ Adolescent rat } \\
\hline Water (control) & 0 & $45 \pm 4.0$ & $1.0 \pm 0.1$ & $0.9 \pm 0.1$ & $1.0 \pm 0.1$ & $0.2 \pm 0.01$ \\
\hline Glucose & 3 & $40 \pm 5,8$ & $1.1 \pm 0.1$ & $1.1 \pm 0.1$ & $1.2 \pm 0.2$ & $0.2 \pm 0.01$ \\
\hline Sucrose & 3 & $54 \pm 3.0$ & $1.4 \pm 0.1$ & $1.4 \pm 0.2$ & $1.8 \pm 0.3$ & $0.3 \pm 0.02$ \\
\hline Lactose & 3 & $81 \pm 2.5^{3}$ & $1.7 \pm 0.1^{3}$ & $1.6 \pm 0.1^{3}$ & $2.0 \pm 0.1^{3}$ & $0.3 \pm 0.01^{3}$ \\
\hline
\end{tabular}

${ }^{1}$ Values are mean \pm S.E., $8-10$ rats were used in each treatment group.

${ }^{2}$ Mean values in the suckling rats were significantly greater than corresponding mean values in the adolescent rats $(P<0.05-0.001)$

${ }^{3}$ Mean values in the lactose fed adolescent rats are significantly greater than corresponding mean values in rats fed water, glucose, and sucrose $(P$ $<0.05)$. 
by removing an energy-dependent brush border barrier to calcium (20), or by modifying the transmural potential of the intestine (15). Recently, Wasserman (21) using a Ussing Chamber, was able to show that as lactose concentration was increased in the bathing media, the membrane potential in both the duodenum and the ileum was decreased. Consequently the intestinal membranes become more permeable to calcium, resulting in greater net absorption. These studies confirmed the previously published observation that lactose had to be in the same intestinal segment as the calcium to exert its effect. The observed enhancement of minerals with lactose in the adolescent rats may be related to the prolonged presence of lactose in the intestinal lumen secondary to the decline in the activity of lactase in the intestinal brush border membrane which occurs after the suckling period.

Our findings that lactose had no effect on mineral absorption in the suckling period may be related to two factors. First, the high lactase activity in the suckling rats results in rapid hydrolysis of dietary lactose to glucose and galactose, both of which have been shown to have no effect on mineral absorption in postweanling rats (5). Second, our previous studies have indicated that the permeability coefficient in the suckling rats intestine was significantly greater compared to that of the adolescent rats $(10,16,17)$. Such increased permeability with greater net absorption rates of minerals may mask any effect of lactose on the intestinal absorption process.

\section{REFERENCES AND NOTES}

1. Adams, P. H., Hill, L. F., Wain, D., and Taylor, C.: The effects of undernutrition and its relief on intestinal calcium transport in the rat. Calc. Tissue Res., 16: 293 (1974).

2. Amine, E. K. and Hegsted, D. M.: Effect of diet on iron absorption in iron deficient rats. J. Nutr., 101: 827 (1971).

3. Armbrecht, H. J. and Wasserman, R. H.: Enhancement of $\mathrm{Ca}^{++}$uptake by lactose in the rat small intestine. J. Nutr., 106: 1265 (1976).

4. Brown, W. B., Jr. and Hollander, M.: Statistics: A Biomedical Introduction. p. 90 (John Wiley \& Sons, New York, NY, 1977).
5. Bushnell, P. J. and Deluca, H. F.: Lactose facilitates the intestinal absorption of lead in weanling rats. Science, 211: 61 (1981).

6. Charley, P. and Saltman, P.: Chelation of calcium by lactose: its role in transport mechanisms. Science, 139: 1205 (1963).

7. Fournier, P. and Digaud, A.: Influence de l'ingestion de lactose sur l'absorption et la retention du zinc. C. R. Acad. Sci. Ser. D., 272: 3061 (1971).

8. Fournier, P. and Fournier, A: Influence de l'ingestion de lactose sur l'absorption et la retention du manganese. C. R. Soc. Biol., 166: 29 (1972).

9. Fournier, P.: Influence de l'ingestion de lactose sur l'absorption et la retention du cobalt. C. R. Soc. Biol., 168: 244 (1974).

10. Ghishan, F. K., Jenkins, J. T., and Younoszai, M. K.: Maturation of calcium transport in the rat small and large intestine. J. Nutr., 110: 1622 (1980).

11. Henning, S. T. and Kretchmer, N.: Development of intestinal function in mammals. Enzyme, 15: 3 (1973).

12. Kimberg, D. V., Schachter, D., and Schenker, H.: Active transport of calcium by the intestine: effect of dietary calcium. Am. J. Physiol., 200(6): 1256 (1961).

13. Leichter, J.: Effect of dietary lactose on intestinal lactase activity in young rats. J. Nutr., 103: 392 (1973).

14. Lengemann, F. W.: The site of action of lactose in the enhancement of calcium utilization. J. Nutr., 69: 23 (1959).

15. Martin, D. L. and Deluca, H. F.: Influence of sodium on calcium transport by the rat intestine. Am. J. Physiol., 216: 1351 (1969).

16. Meneely, R. L. and Ghishan, F. K.: In vivo zinc transport in normal and growth retarded infant rats. Clin. Res. Abstract, 28: 821 (1980).

17. Meneely, R. L., Leeper, L., and Ghishan, F. K.: Intestinal maturation: In vivo magnesium transport. Pediatr. Res., 16: 295 (1982).

18. Milhaud, G., Cherian, A. G., and Moukhtar, M. S.: Calcium metabolism in the rat studied with ${ }^{45}$ calcium: effect of age. Proc. Soc. Exp. Biol. Med., 114: 382 (1963).

19. Smith, C. M., Deluca, H. F., Tanaka, Y., and Mahaffey, K. R.: Stimulation of lead absorption by vitamin D administration. J. Nutr., 108: 843 (1978).

20. Wasserman, R. H.: Lactose stimulated intestinal absorption of calcium: A theory. Nature, 201: 997 (1964).

21. Wasserman, R. H.: Lactose and calcium absorption. "Ross clinical research conference". (1979).

22. This study was supported by Diabetes Research and Training Center, AM 2059303 and Clinical Research Center Grant No. RR 00095.

23. Requests for reprints should be addressed to: Dr. Fayez K. Ghishan, Associate Professor, Department of Pediatrics, Vanderbilt Medical Center, Nashville, TN 37232.

24. Received for publication September 15, 1981

25. Accepted for publication December 9, 1981. 